\title{
ANALISIS PROGRAM PELATIHAN KADER PAUD TERINTEGRASI KELURAHAN ULAK KARANG SELATAN KOTA PADANG
}

\author{
Yaswinda ${ }^{1}$, Yulsyofriend, Yaslina ${ }^{2}$, Elida $^{4}$ \\ ${ }^{1}$ PG PAUD Universitas Negeri Padang \\ ${ }^{2}$ PG PAUD Universitas Ngeri Padang \\ ${ }^{3}$ Stikes Perintis \\ ${ }^{4}$ FPP Universitas Negeri Padang
}

Email : yaswinda@fip.unp.ac.id ,yulsyofriend@fip.unp.ac.id

\begin{abstract}
ABSTRAK
Penelitian ini bertujuan untuk mengevaluasi kegiatan pelatihan Pendidikan Anak Usia Dini (PAUD) terintegrasi yang didirikan melalui kegiatan Program Kemitaran Wilayah yang dilaksanakan di wilayah pesisir Kelurahan Ulak Karang Selatan, Kota Padang, Metode yang digunakan dalam penelitian ini menggunakan metode evaluasi program dengan model Context - input - process - product (CIPP). Sumber data adalah 20 orang kader posyandu balita dan kader Pos PAUD di kelurahan Ulak Karang Selatan serta orang tua anak PAUD. Data diperoleh dari hasil penyebaran angket, wawancara, observasi dan dokumentasi berupa foto. Teknik analisis data yang di gunakan adalah analisis deskriptif kualitatif dan kuantitatif data berupa porsentasi. Teknik pengumpulan data penelitian adalah wawancara, observasi, dan analisis dokumen. Kegiatan yang dievaluasi berjalan selama bulan April 2019 - Oktober 2019. Berdasarkan analisis CIPP, maka program pelatihan telah berjalan dengan baik. Setelah dilakukan pelatihan kader terdapat inovasi dalam pengembangan POS PAUD integrasi ini. Layanan termasuk penyebaran pengetahuan makanan yang sehat untuk balita, sesuai rencana tim program kemitraan wilayah dengan melibatkan banyak pihak dan memberikan dampak manfaat bagi anak usia dini dan orang tua serta kader posyandu balita.
\end{abstract}

Kata Kunci: PAUD terintegrasi; kader PAUD; analisis model CIPP

\begin{abstract}
This study aims to evaluate integrated Early Childhood Education (ECE) training activities that were established through the Regional Maritime Program activities carried out in the coastal areas of Ulak Karang Selatan Village, Padang City. The method used in this study uses a program evaluation method using the Context - input model - process - product (CIPP). Data sources are 20 posyandu cadres under five and ECE cadres in Ulak Karang Selatan village and parents of ECE. Data obtained from the distribution of questionnaires, interviews, observations, and documentation in the form of photographs. The data analysis technique used is descriptive qualitative and quantitative data analysis in the form of poration. Research data collection techniques are interviews, observation, and document analysis. The activities that were evaluated are running from April 2019 - October 2019. Based on the CIPP analysis, the training program has been running well. After the cadre training was carried out, there was an innovation in the development of this integrated ECE. Services include the dissemination of knowledge of healthy food for toddlers, according to the regional partnership program team plan by involving many parties and providing beneficial impacts for early childhood and parents and posyandu cadres for toddlers Keywords: CIPP model, early childhood education.
\end{abstract}


Yaswinda, Yulsyofriend, Yaslina, Elida

\section{ANALISIS PROGRAM PELATIHAN KADER PAUD TERINTEGRASI KELURAHAN ULAK KARANG SELATAN KOTA PADANG \\ Early Childhood: Jurnal Pendidikan. Vol. 3 No. 2., November 2019}

Keyword: cadress, early childhood education, model CIPP

\section{PENDAHULUAN}

Secara umum Kelurahan Ulak Karang Selatan memiliki luas 106 ha dengan batas-batas wilayah sebagai berikut:Utara; kelurahan Ulak karang Utara, Selatan: Kelurahan Lolong Belanti, barat: Samudera Hindia, dan Timur: kelurahan Gunung Panggilun. Dari segi geografis Kelurahan Ulak Karang Selatan terletak pada ketinggian 0-8 M dpl dari permukaan laut dengan suhu rata-rata $31 \mathrm{oC}$. Dari segi administrasi pemerintahan, Kelurahan Ulak Karang Selatan dibagi atas 13 (tiga belas) Rukun Warga (RW) dan 43 (empat puluh tiga) Rukun Tetangga (RT). Jumlah penduduk hingga akhir Desember 2017 adalah 8741 jiwa, 2185 KK dengan perincian 4357 laki-laki dan 4384 perempuan. Daerah Kelurahan ini secara garis besar dapat dibagi menjadi 2 bagian yaitu daerah pesisir yang meliputi wilayah RW 01, 02, dan 03. Pendidikan rata-rata warganya terdiri dari SLTA $60 \%$, Perguruan tingi $30 \%$, dan putus sekolah 10\%. Pada umumnya yang putus sekolah dari masayarakat nelayan. Wilayah yang ditempati nelayan sebagian besar berada di RW 01, 02 dan 03, karena ketiga wilayah tersebut bersinggungan langsung dengan laut Samudera Hindia. Di wilayah pesisir terdapat 1 puskesmas pembantu dan 6 posyandu balita dan 1 posyandu lansia.

Daerah pantai Ulak Karang Selatan yang merupakan wilayah pesisir telah dicanangkan sebagai Kampoeng Nelayan pada tahun 2018 ini, telah mendapatkan dukungan oleh berbagai pihak, pemuka masyarakat, ketua RT/RW, Camat dan Dinas Kelautan Kota Padang. Sebagai Kelurahan berprestasi pertama di kota Padang dan prestasi terbaik dua di Sumatera Barat tahun 2018, Kelurahan ini tetap terus berbenah. Gerakan Lihat Sampah Ambil (Gelisa) berupa gerakan ambil sampah yang dilakukan oleh anak-anak sekolah sebelum masuk kelas dan program simpan data penduduk (Simpada-Duk) dimana kelurahan menyimpan data penduduk sehingga masyarakat dipermudah dalam layanan publik di kelurahan, sehingga tidak perlu bawa fotocopi KTP jika ingin melakukan pengurusan di Kelurahan. Kelurahan juga sudah melakukan pemberdayaan pemuda dan wanita nelayan dengan mendorong mereka menjadi pelaku usaha dengan memberikan program keterampilan.

Lurah Ulak Karang Selatan terus berusaha untuk mengembangkan potensi yang ada di daerahnya. Ketika tim kami melakukan wawancara dengan pak Lurah, mengaku bahwa dibalik kesuksesan kelurahannya menjadi terbaik pertama di kota Padang dan terbaik dua di Sumatera Barat, Beliau mengakui kekurangan kelurahannya adalah program posyandu yang belum berjalan optimal. Berdasarkan wawancara dan hasil observasi ke wilayah pesisir, khususnya wilayah RW 01 ternyata di wilayah pesisr/ pantai ini belum ada lembaga PAUD, padahal anak balita yang ada di wilayah tersebut cukup banyak yaitu 36 anak. Kelurahan 

KELURAHAN ULAK KARANG SELATAN KOTA PADANG

juga berkeinginan memiliki posyandu Lanjut Usia (lansia) dan anak bawah lima tahun (balita) yang terintergrasi dengan program-program yang inovatif dan dapat menjadi rujukan kelurahan lain di kota Padang dan Sumatera Barat.

Berdasarkan hasil wawancara dengan kader posyandu, Posyandu Balita di kelurahan UKS didirikan pada tahun 2001 telah melaksanakan program berupa penimbangan dan pengukuran berat dan tinggi badan, imunisasi, dan pemberian makanan tambahan yang dilaksanakan sebulan sekali. Posyandu Lansia baru ada sejak tahun 2007 yang juga dilakukan sebulan sekali dengan program yang berjalan berupa pengukuran tensi. Pada tahun pendirian posyandu lansia sempat ada program pemberian obat-obatan ringan, senam dan pemberian makanan tambahan, namun sudah bebrapa tahun ini, program tersebut tidak berjalan. Hal ini berkaitan dengan pendanaan. Posyandu RW 01 dilaksanakan di tanah fasiltas umum yang memiliki tanah yang cukup luas dan bagunan yang merangkap sebagai pos pemuda.

$\begin{array}{rrr}\text { Pos } & \text { Pelayanan Terpadu }\end{array}$ pelayanan dalam wilayah kerja tertentu dengan kegiatan terpadu, yang bersifat dari, oleh dan untuk masyarakat secara terpadu dengan program-program dari instansi terkait untuk mencapai tujuan Keluarga Kecil Bahagia Sejahtera atau KKBS. Instansi tersebut melalui Departemen Kesehatan, BKKBN, Depdagri, PKK serta sector lainnya.
Posyandu mempunyai dua kegiatan pokok, yaitu penyuluhan dan pelayanan kesehatan. Kegiatan Posyandu mencakup 5 hal pokok, yaitu pendaftaran, penimbangan, pemberian makan tambahan, imunisasi, dan penyuluhan kesehatan. Balita memerlukan stimulasi yang tepat untuk membantu tumbuh kembangnya. Stimulasi bisa dilakukan di rumah dan di tempat pendidikan anak usia dini. Kader posyandu yang selama ini menjadi binaan puskesmas kelurahan Ulak Karang selatan melayani tumbuh kembang berupa pemberian makanan tambahan, menimbang berat badan dan mengukur tinggi badan serta pemberian imunisasi. Namun hal itu tentu tidak cukup untuk mencapai harapan tumbuh kembang karena anak membutuhkan stimulasi. Salah satu stimulasi yang dapat diberikan kepada anak balita adalah stimulasi di lembaga Pendidikan Anak Usia Dini (PAUD) yang terintegrasi.

Amanat UU telah menetapkan agar pemerintah menyisihkan 20\% dari APBN adalah untuk dialokasikan pada sektor pendidikan. Perhatian pemerintah terhadap PAUD erat hubungannya dengan penyiapan SDM berkualitas dan pertumbuhan ekonomi di kemudian hari. Hubungan investasi sumber daya manusia (pendidikan) dengan pertumbuhan ekonomi merupakan dua mata rantai. Anak usia dini merupakan sosok yang sedang menjalani suatu proses perkembangan dengan pesat dan fundamental bagi kehidupan 
Yaswinda, Yulsyofriend, Yaslina, Elida

ANALISIS PROGRAM PELATIHAN KADER PAUD TERINTEGRASI KELURAHAN ULAK KARANG SELATAN KOTA PADANG

Early Childhood: Jurnal Pendidikan. Vol. 3 No. 2., November 2019

selanjutnya. Pendidikan anak usia dini tidak sekedar memberikan pengalaman belajar kepada anak, tetapi yang lebih penting untuk mengoptimalkan perkembangan otak anak, pendidikan anak usia dini juga mencakup seluruh proses stimulasi psikososial (Sujiono:2012). Pendidikan anak usia dini (PAUD) adalah suatu upaya untuk pembinan yang ditujukan kepada anak sejak lahir sampai usia 8 tahun yang dilakukan melalui pemberian ransangan pendidikan untuk membantu pertumbuhan dan perkembangan jasmani dan rohani agar anak memiliki kesiapan memasuki pendidikan lebih lanjut (tRianto: 2011).

Pemerdayaan masyarakat merupakan upaya untuk meningkatkan harkat dan martabat lapisan masyarakat yang dalam kondisi sekarang yang tidak mampu melepaskan diri dari perangkap kemiskinan dan keterbelakangan. Dengan itu memberdayakan masyarakat berarti memberikan kemampuan dan kemandirian masyarakat. Yang mana dilakukan dalam pendekatan pemberdayan masyaraakat melalui program-program pemerintah antara lain PNPM-MP dsn penguatan lembaga unit pengelola kecamatan (Manat dkk, 2014).

Berdasarkan analisis situasi dan permasalahan yang telah diungkapkan, dapat diidentifikasikan bahwa permasalahan dalam Program Kemitraan Wilayah yang muncul di kelurahan Ulak Karang Selatan (UKS) diantaranya masalah pendidikan yaitu kurangnya prasarana dan sarana pendidikan yang telah ada untuk anak usia dini dan belum tersedianya lembaga Pendidikan Anak Usia Dini (PAUD) terintegrasi di wilayah pesisir. Karena itu, tahun pertama, kami fokuskan program pemberdayaan balita melalui pendirian PAUD terintegrasi dengan mengintegrasikan layanan pendidikan dalam satu tempat layanan kesehatan dengan jadwal yang terprogram dengan terlebih dahulu memberikan pelatihan bagi kader posyandu balita yang menjadi kader pos PAUD terintegrasi.

Untuk menentukan hasil yang telah dicapai beberapa kegiatan yang direncanakan dan mendukung tercapainya tujuan pelatihan, serta melihat kembali apakah suatu program atau kegiatan pelatihan telah dapat dilaksanakan sesuai dengan perencana, maka perlu dilakukan evalusi program. Program adalah suatu rangkaian kegiatan sebagai bentuk implementasi dari suatu kebijakan. Menurut pengertian secara umum, program diartikan sebagai "rencana" yang akan dilakukan oleh seseorang atau suatu organisasi dalam rangka mencapai tujuan. Namun apabila program tersebut dikaitkan dengan evaluasi program, maka program didefinisikan sebagai suatu unit atau kesatuan kegiatan yang merupakan realisasi atau implementasi dari suatu kebijakan, berlangsung dalam proses yang berkesinambungan, dan terjadi dalam suatu organisasi yang melibatkan sekelompok orang (Suharsimi dan Cepi Safruddin, 2009). Evaluasi program dilakukan untuk 
Yaswinda, Yulsyofriend, Yaslina, Elida

\section{ANALISIS PROGRAM PELATIHAN KADER PAUD TERINTEGRASI KELURAHAN ULAK KARANG SELATAN KOTA PADANG \\ Early Childhood: Jurnal Pendidikan. Vol. 3 No. 2., November 2019}

kepentingan pengambilan keputusan dalam rangka menentukan kebijakan selanjutnya. Menurut Tyler dalam Suharsimi (2009) mengemukakan bahwa evaluasi program adalah proses untuk mengetahui apakah tujuan pendidikan sudah dapat terealisasikan. Sedangkan menurut Cronbach dalam Wirawan (2011) menyatakan bahwa. evaluasi adalah sebagai bagian yang integral dari penelitian kebijakan yang menfokuskan pada masyarakat pembentuk kebijakan dan memerlukan potensi akomodasi politik.

Untuk tersebut yang menjadi mejadi masalah dalam tulisan ini adalah: (1) Apa yang menjadi kebutuhan program pelatihan PAUD terintegrasi di Kelurahan Ulak Karang Selatan kota Padang ?; (2) Bagaimana program pelatihan PAUD terintegrasi di Kelurahan Ulak Karang Selatan kota Padang yang telah dilaksanakan ?; (3) Bagaimana implementasi program PAUD terintegrasi di Kelurahan Ulak Karang Selatan kota Padang ?; dan (4) Bagaimana dampak atau pengaruh program PAUD terintegrasi di Kelurahan Ulak Karang Selatan kota Padang setelah pelatihan kader ?

Tujuan dilakukannya evalusi program Pelatihan Kader Paud Terintegrasi Di Kelurahan Ulak Karang Selatan Kota Padang adalah : (1) Untuk mengetahui konteks dari program pelatihan PAUD terintegrasi di Kelurahan Ulak Karang Selatan kota Padang yang telah dilaksanakan, khususnya mengenai dukungan konteks terhadap implementasi program; (2) ntuk mengetahui seberapa jauh program pelatihan PAUD terintegrasi di Kelurahan Ulak Karang Selatan kota Padang yang telah dijalankan tersebut memiliki relevansi terhadap kelompok sasaran, sesuai dengan tujuan dari program tersebut; (3) Untuk melakukan kajian mengenai seberapa jauh pelaksanaan program pelatihan PAUD terintegrasi di Kelurahan Ulak Karang Selatan kota Padang tersebut telah sesuai dengan rencana program yang telah disusun; dan (4) Untuk mengkaji faktorfaktor penentu keberhasilan implementasi program pelatihan PAUD PAUD terintegrasi di Kelurahan Ulak Karang Selatan kota Padang setelah pelatihan kader PAUD dilaksanakan.

\section{METODE PENELITIAN}

Model evaluasi program yang akan digunakan dalam makalah ini adalah Model CIPP ini dikembangkan oleh Stufflebeam. Sasaran dari kegiatan ini dijadikan sebagai responden atau sumber data yaitu diambil secara proposional sejumlah 20 orang kader posyandu balita yang dikader menjadi kader/ guru PAUD, kader pAUD dan orang tua, di kelurahan Ulak Karang Selatan. Data diperoleh dari hasil penyebaran angket saat pelatihan secara teori, wawancara setelah 4 bulan pelatihan setelah pelaksanaan pelatihan praktik serta studi dokumentasi berupa foto.Teknik analisis data yang di gunakan adalah analisis deskriptif 
Yaswinda, Yulsyofriend, Yaslina, Elida

ANALISIS PROGRAM PELATIHAN KADER PAUD TERINTEGRASI KELURAHAN ULAK KARANG SELATAN KOTA PADANG

Early Childhood: Jurnal Pendidikan. Vol. 3 No. 2., November 2019

kualitatif dan kuantitatif data berupa porsentasi. Variabel dalam evaluasi ada 4 yaitu : variabel Context, Input, Process dan Product. Variabel Context mendeskripsikan relevansi program pelatihan terhadap pemenuhan kebutuhan. Variabel Input meliputi: karakteristik peserta, materi pelatihan, sarana penunjang dan pengelolaan program. Variabel Proccess meliputi partisipasi peserta dan kualitas pelaksanaan kegiatan. Variabel Product meliputi manfaat program pelatihan atau hasil yang diperoleh.

\section{HASIL DAN PEMBAHASAN}

Hasil dalam evaluasi program dibagi menjadi 4 pokok variabel yaitu : (1) Evaluasi konteks berarti untuk menjawab "Apa yang perlu (kebutuhan) dilakukan?". Evaluasi ini mengidentifikasi kebutuhan-kebutuhan yang mendasari disusunnya program. Juga untuk mengidentifikasi waktu pelaksanaan program serta keputusan untuk perencanaan program yang mengarah pada desain program; (2) Evaluasi input/masukan berupaya menjawab pertanyaan "Apa yang harus dilakukan?" waktu pelaksanaan sebelum program dilakukan serta keputusan adalah?; (3) Evaluasi proses berupaya untuk menjawab " Apakah program sedang dilaksanakan?” dengan mengidentifikasi kekurangan program dan memeperbaiki impelmentasinya; dan (4) Evaluasi produk untuk menjawab "Apakah keluaran program ?" dengan mengidentifikasi keluaran yang

direncanakan maupun tidak

direncanakan

\section{Apa saja yang menjadi kebutuhan} program ? (Variabel Context)

Pelatihan yang baik perlu perencanaan yang matang, mulai dari mempersiapkan tujuan, instrumen pelatihan, Fasilitator, Program Pelatihan, Materi Pelatihan, Pengelolaan,Pelaksanaan serta evaluasi pelatihan. Kegiatan pelatihan ini bertujuan untuk : Mengembangkan wawasan kader posyandu balita dalam bidang PAUD dalam hal mengajar di PAUD terintegrasi dengan posyandu dan Mengembangkan keterampilan guru PAUD dalam hal membuat permaianan membaca AUD;

Untuk mencapai tujuan pelatihan secara optimal, maka dilakukan analisis kebutuhan, kegiatan yaitu Persiapan kegiatan ini membutuhkan : menentukan tempat sasaran pelatihan, dan persiapan untuk pelaksanaan pelatihan seperti meyiapkan materi pelathan berupa hand out, instrument pre test dan post test sendiri yang akan ditampilkan pada pelatihan dan bahan diperlukan dalam pelatihan

Dalam analisis kebutuhan juga untuk mengidentifikasi waktu pelaksanaan program serta keputusan untuk perencanaan program yang mengarah pada desain program. Berdasarkan analisis kebutuhan, sebelum dilaksanakan pelatihan bagi kader posyandu, terlebih dahulu 
Yaswinda, Yulsyofriend, Yaslina, Elida

ANALISIS PROGRAM PELATIHAN KADER PAUD TERINTEGRASI KELURAHAN ULAK KARANG SELATAN KOTA PADANG

Early Childhood: Jurnal Pendidikan. Vol. 3 No. 2., November 2019

dilkasanakn Fokus Grup Diskusi, (FGD)

. kegiatan ini dilakukan pada tanggal 3 April 2019 di Kantor Kelurahan Ulak karang Selatan. Pada kegiatan ini diundang sebanyak 50 orang yang terdiri dari perwakilan dari kelurahan, kecamatan dan puskesmas RT dan RW di daerah pesisir kelurahan Ulak Karang Selatan, kader posyandu balita dan posyandu lansia serta tokoh masyarakat. Acara ini dihadiri oleh 30 peserta. Pada acara ini para tokoh menyampaikan apresiasinya dan sangat berharap kegiatan ini dapat berlangsung selama 3 tahun, Karena mereka butuh pendampingan yang lebih lama dibandingkan kegiatan yang hanya 1 tahun. Dalam FGD ini juga disampaikan akan adanya seminar dan worshop untuk kader posyandu dan lansia. Berdasarkan kesepakatan tentang waktu seminar, ternyata tidak bias dilaksanakan seminar yang setengah hari penuh atau 1 hari penuh, karena kader adalah ibu rumah tangga, sehingga rencana untuk melaksnaakan seminar untk kader posyandu semua 3 kali (hari) menjadi 6 kali (hari). Para kader hanya bisa berpartisipasi 3 jam/hari. Berdasarkan kesepakatan tersebut kemudia dilakukan acara sesi seminar untuk kader posyandu balita dan posyandu lansia pada tanggal 23 April 2019.

\section{Variabel lnput/Masukan}

Dalam menjawab apa yang harus dilakukan?" maka desain program pelatihan disusun dengan memperhatikan relevasi materi dan kebutuhan perserta terhadapa materi dalam hal ini berarti peserta mengganggap materi tersebut dapat diterapkan dalam kegiatan mengajar di lembaga PAUD. Dalam variabel ini juga termasuk tempat penyelenggaraan pelatihan yang dikategorikan sebagai sarana prasarana.

\section{a) Materi Pelatihan}

Berdasarkan data yang diperoleh, bahwa Pelatihan sudah cukup memenuhi kebutuhan untuk mencapai tujuan pelatihan yaitu dengan pemberian materi yang relevan dengan tujuan pelatihan. Pada hari pertama kegiatan seminar peserta datang tepat waktu yaitu pada jam 08.00 wib, peserta duduk di kursi aula Kelurahan yang telah disediakan oleh panitia. Pemateri pada hari pertama tentang pentingnya Masa Golden Age. Materi yang disampaikan berupa materi tentang pentingnya periode pertama anak, tentang penjelasan apa itu masa golden age, tentang perkembangan otak anak, kognitif, social, emosional, bahasa, dan lain sebagainya. Peserta tampak antusias mengikuti materi dan menulis di buku seminar yang telah disediakan oleh panitia. Peserta juga aktif bertanya kepada nara sumber tentang materi yang tidak peserta pahami dan membandingkan dengan pengalaman mereka sebagai kader posyandu balita ataupun sebagai orangtua yang mengasuh anak usia balita. Penyampaian materi selesai pada pukul 12.00 wib, peserta juga mendapatkan snack atau makanan kotak. 
Pelaksanaan seminar pada hari kedua dilakukan pada hari rabu tanggal 24 April 2019 di aula kantor lurah seperti hari pertama kegiatan seminar. Pada hari kedua peserta datang pada jam 09.00 wib dikarenakan hujan lebat. Panitia menyiapkan buku, pena, dan tas seminar serta snack untuk peserta. Pemateri pada hari kedua dengan tema materi "belajar sambil bermain". Pemateri menjelaskan secara teoritis dan praktis apa yang dimaksud dengan belajar sambil bermain, selanjutnya peserta diajak untuk mencontohkan bagaimana cara memberikan pembelajaran yang menyenangkan pada anak terkait tema belajar sambil bermain. Peserta dilatih melakukan gerakan dan nyanyian untuk anak-anak. Peserta tampak antusias mengikuti materi dan gerakan serta nyanyian secara bersama. Setalah pelatihan belajar sambil bermain, pemateri mengajak peserta untuk berbagi pengalaman mengajar anakanak ataupun mengasuh anak balita, dan juga diselingi dengan diskusi tanya jawab antara peserta dan pemateri.

Setelah kegiatan seminar dan pelatihan dilakukan, maka tahap selanjutnya dilakukan workshop pada hari Selasa tanggal 13 Mei 2019. Tema workshop yakni Penyusunan KTSP. Pembahasan workshop meliputi tentang persyaratan tentang mendaftarkan anak, visi dan misi PAUD, tujuan, cara mencapai tujuan, jam belajar, tata cara pelaksanaan, sarana dan prasarana, sumber daya manusia, tenaga kependidikan dan pelaksanaan kegiatan sekolah. Para kader diminta untuk mendata kembali anak yang usia 3-4 tahun dilingkungan RW mereka. Peserta mengatakan waktu pelatihan penegtahuan cukup, namun waktu yang disediakan untuk praktik masih kurang.

Berdasarkan hasil data sumber yang berkaitan dengan materi pelatihan kepada 20 peserta diperoleh hasil sebagai berikut.

\section{Tabel 1. Materi Pelatihan}

\begin{tabular}{|l|l|l|l|l|l|}
\hline No & Kriteria & Indikator & \multicolumn{3}{|l|}{ Penilaian } \\
\cline { 3 - 6 } & & & baik & cukup & kurang \\
\hline 1 & $\begin{array}{l}\text { Materi } \\
\text { pelatih } \\
\text { an }\end{array}$ & $\begin{array}{l}\text { Materi yang } \\
\text { diberikan } \\
\text { relevan dengan } \\
\text { judul pelatihan }\end{array}$ & 18 & 2 & 0 \\
\cline { 3 - 5 } & & $\begin{array}{l}\text { Materi } \\
\text { pelatihan dapat } \\
\text { diterapkan } \\
\text { dalam } \\
\text { penbelajaran } \\
\text { AUD }\end{array}$ & 17 & 2 & 1 \\
& & & & \\
\hline
\end{tabular}

Berdasarkan jawaban responden tentang relevansi materi pelatihan menunjukkan $90 \%$ (18 peserta) menilai baik; $10 \%$ (2 peserta) cukup;0 \% (0 peserta) menilai kurang. hasillain kusioner tentang materi, Materi pelatihan dapat diterapkan dalam penbelajaran AUD, menunjukkan $85 \%$ (17 peserta) menilai baik; $10 \%$ (2 peserta) cukup; $5 \%$ (1 peserta) menilai kurang.

\section{b) Sarana Prasarana}

Berdasarkan hasil data sumber yang berkaitan dengan sarana dan prasarana pelatihan kepada 20 peserta pelatihan diperoleh hasil sebagai berikut. 
Yaswinda, Yulsyofriend, Yaslina, Elida

ANALISIS PROGRAM PELATIHAN KADER PAUD TERINTEGRASI KELURAHAN ULAK KARANG SELATAN KOTA PADANG

Early Childhood: Jurnal Pendidikan. Vol. 3 No. 2., November 2019

Tabel 2. Tempat Pelatihan

\begin{tabular}{|c|c|c|c|c|c|c|}
\hline \multirow[t]{2}{*}{$\begin{array}{l}\text { Pengeta } \\
\text { huan }\end{array}$} & \multicolumn{3}{|c|}{ Sebelum Edukasi } & \multicolumn{3}{|c|}{$\begin{array}{l}\text { Sesudah } \\
\text { Edukasi }\end{array}$} \\
\hline & $\mathrm{F}$ & $\%$ & Mean & $\mathrm{F}$ & $\%$ & $\begin{array}{l}\text { Mea } \\
\mathrm{n}\end{array}$ \\
\hline 1.Tinggi & 13 & 71,5 & 72.61 & 18 & 90 & 84.4 \\
\hline Rendah & 7 & 28,5 & & 2 & 10 & 6 \\
\hline Jumlah & 20 & $\begin{array}{c}100 \\
\%\end{array}$ & & 20 & $\begin{array}{c}10 \\
0 \\
\%\end{array}$ & \\
\hline
\end{tabular}

Berdasarkan jawaban responden tentang Tempat penyelengaraan nyaman dan menyenangkan, menunjukkan $80 \%$ (16 peserta) menilai baik; $15 \%$ (3 peserta) cukup;5 \% (1 peserta) menilai kurang.

\section{Variabel Process}

Dalam Evaluasi proses berupaya untuk menjawab " Apakah program sedang dilaksanakan?” dengan mengidentifikasi kekurangan dan kelebihan program pelatihan yang dilakukan. Kelebihan dan kekurangan program dilihat dari partisipasi perserta, kualitas pelaksanaan dan pengeloloaan program.

\section{a). Partisipasi peserta}

Berdasarkan hasil data absensi selama pelatihan diperoleh data partisipasi peserta secara umum baik. Kemudian hasil pre test dan post test tergambar sebagai berikut ini.

Tabel 3. Kemudian hasil pre test dan post test tergambar sebagai berikut ini.

Daftar kehadiran peserta dalam pelatihan rata-rata $85 \%$.

\section{b) Kualitas Pelaksanaan Program Pelatihan}

Dalam pelaksanaan kegiatan pelatihan ini digunakan langkah berikut ini, yaitu: Untuk pemberian informasi digunakan metode ceramah dimana para

nara sumber menyajikan makalah dan setelah itu dilakukan tanya jawab.

\section{Variabel Product}

\section{Manfaat Program Pelatihan bagi Peserta}

Berdasarkan hasil data sumber yang berkaitan dengan waktu pelatihan (Hasil evaluasi pelatihan yang dilakukan sebelum acara penutupan (saat pelatihan berlangsung) kepada 20 peserta pelatihan) diperoleh hasil wawancara dengan beberapa orang kader bahwa acara ini sangat bermanfaat. Produk yang dihasilkan dari pelatihan ini lahirnya sebuah PAUD terintegrasi di daerah Pesisir wilayah kelurahan Ulak Karang Selatan dengan nama PAUD Pasia Mutiara. Nama PAUD ini diusulkan oleh salah seorang kader dengan filosofi yaitu anak-anak pasia (pesisir pantai) yang tadi nya belum mendapatkan stimulasi PAUD yang optimal setelah masuk menjadi siswa di PAUD Pasia Mutiara menjadi anak yang baik dan sholeh serta sholehah dengan tahap perkembangan yang optimal.

Sebagai wujud partisipasi masyarakat sekitar maka, sebelum PAUD dimulai, dilaksanakan gotong royong membersihkan tempat yang akan 
Yaswinda, Yulsyofriend, Yaslina, Elida

ANALISIS PROGRAM PELATIHAN KADER PAUD TERINTEGRASI KELURAHAN ULAK KARANG SELATAN KOTA PADANG

Early Childhood: Jurnal Pendidikan. Vol. 3 No. 2., November 2019

dijadikan PAUD terintegtasi tersebut. Pelaksanaan gotong royong bersama panitia dan kader dilakukan di sekolah PAUD Pasia Mutuara di Jl. Hiu Ulak karang selatan pada hari minggu 27 juli 2019 Panitia dan kader membuat hiasan jendela sekolah bertema geometri dan warna-warni, mempersiapkan fasilitas belajar mengajar, lemari, karpet, dan media pembelajaran.

Hari pertama kagiatan belajar mengajar dilakukan pada hari senin, 29 Juli 2019. Hari pertama sekolah diisi dengan kegiatan perkenalan, saling mengenal dengan lingkungan sekolah (orientasi), bersama orangtua, guru dan teman-teman. Terlihat anak-anak penasaran dengan kegiatan disekolah, anak antusias, bersemangat, tersenyum, dan attention terpusat kepada guru. Jumlah anak pada hari pertama sekolah adalah 15 orang anak. Kegiatan pada hari pertama yaitu, menempel bentuk diri (kepala, badan, tangan, kaki). Nilai yang terkandung dalam kegiatan ini yakni membiasakan budaya antri. Setelah selesai kegiatan menempel anak mencuci tangan, menyanyi, dan mengambil makanan secara bergilir/ antri. Jumlah anak yang dating pada hari pertama yaitu 17 orang anak, kader 3 orang dan tim 4 orang. Anak yang tidak hadir beerjumlah 3 orang.

Hari kedua sekolah dilakukan pada hari rabu, 31 juli 2019. Kegiatan sekolah dimulai pada pukul 08.00 wib, anak dipandu oleh guru untuk membentuk lingkaran besar berpegangan tangan dan bernyanyi, selanjutnya anak diperkenalkan dengan ukuran gambar besar dan kecil, kemudian anak diminta untuk mengurutkan (ordering) gambar orang, setelah anak berhasil melakukan kegiatan mengurutkan, anak diminta untuk menempelkan hasil karya anak pada papan hasil karya ku dengan cara antri, dan anak diminta untuk berkumpul kembali dan bernyanyi bersama, membaca doa makan dan bersiap untuk makan, makan bersama, doa pulang sekolah dan bermain dihalaman sekolah dan pulang. Jumlah anak yang hadir yakni 17 orang, kader 3 orang dan tim 5 orang. Anak yang tidak hadir berjumlah 3 orang.

Hari ketiga sekolah dilakukan pada hari kamis, 1 agustus 2019. Kegiatan pada hari ketiga ialah memasukkan bola ke keranjang, menciplak telapak tangan. Anak-anak sangat antusias, akan tetapi anak sulit diajak untuk antri saat melemparkan bola. Anak yang tidak hadir berjumlah 4 orang. Anak yang hadir berjumlah 15 orang anak, kader 3 orang dan tim 2 orang.

Hari keempat sekolah dilakukan pada hari senin, 5 agustus 2019. Kegiatan sekolah pada hari keempat yaitu merobek kertas, meremas kertas (melatih kemampuan motoric anak), mengenal ekspresi emosi (menangis, marah, tersenyum), menggunting, menempel, bernyanyi, doa makan, makan bersama, bermain, doa pulang sekolah dan pulang sekolah bersama. Pada hari ketiga anak masih ditemani oleh orangtua di dalam kelas, anak masih sangat ketergantungan dengan orangtua. 
Yaswinda, Yulsyofriend, Yaslina, Elida

\section{ANALISIS PROGRAM PELATIHAN KADER PAUD TERINTEGRASI KELURAHAN ULAK KARANG SELATAN KOTA PADANG \\ Early Childhood: Jurnal Pendidikan. Vol. 3 No. 2., November 2019}

Masih ada beberapa anak yang menangis seperti raziq dan saskia. Saat makan bersama terdapat orangtua yang menyuapkan anak.

Hari ke lima sekolah dilakukan pada hari rabu, 07 agustus 2019. Anak yang hadir berjumlah 11 orang anak, kegiatan belajar mengajar dimulai pada pukul 08.20 wib. Kegiatan sekolah pada hari ke lima yaitu bernyanyi, mendengarkan guru bercerita menggunakan big book, mencocokkan, menempel, makan, bermain, doa pulang sekolah dan pulang sekolah bersama. Pada hari ke lima minggu ke-2 sekolah beberapa anak sudah dapat ditinggal mandiri oleh orangtua di dalam kelas, orangtua murid menunggu di luar kelas. Hanya ada 2 anak yang masih ditunggu oleh orangtua di dalam kelas. Kegiatan sekolah selesai pada pukul 10.00 wib. Anak yang hadir berjumlah 11 orang anak, kader 3 orang, tim 5 orang.

Hari ke enam sekolah dilakukan pada hari kamis, 08 agustus 2019. Anak yang hadir berjumlah 13 orang anak, kegiatan belajar mengajar dimulai pada pukul 08.30 wib. Kegiatan sekolah pada hari ke enam yaitu bernyanyi, berdoa, bermain bola kecil dan berhitung, bermain bola basket (out door), masuk kelas, makan bersama, doa pulang sekolah dan pulang sekolah bersama. Pada kegiatan belajar berhitung sembari bermain bola, anak-anak di pandu oleh guru, sebelum mulai permainan, terlebih dahulu guru menjelaskan tata cara bermain bola dan angka. Anak bermain memasukkan bola kedalam ember dengan cara berlari secara bergantiam di dalam kelas, anak belum memiliki perhatian penuh pada suatu perintah yang panjang, beberapa anak sulit di ataur untuk tertib saat bermain di dalam kelas. Pada saat bermain bola basker di luar ruangan (out door) anak berebutan bola, bersikap egois, beberapa anak yang lain mampu mengikuti intruksi guru secara tertib. Anak di intruksikan oleh guru untuk membentuk 3 kelompok dan bergantian memasukkkan bola basket ke dalam keranjang.

Untuk mengukur bermanfaatan hasil pelatihan, peneliti melakukan pengamatan pada 3 kader yang rajin datang lembaga PAUD bagaimana guruguru tersebut menerapkan pada anak didiknya. Fasilitator melakukan pengamatan mendalam kepada 3 orang peserta pelatihan dan 7 orang tua siswa dengan mengajukan wawancara dengan hasil wawancara sebagai berikut :

1). Bagaimana minat anak dengan PAUD? Pada umumnya mereka menjawab bahwa minat anak sangat tinggi. Ini ditandai dengan biasaya anak tidak mau bangun pagi, namun karena mereka sekarang masuk PAUD, pagipagi mereka sudah bangun dan minta mandi serta diantar ke PAUD

2). Bagaimana kegiatan permaianan di PAUD berlangsung ? pada umumnya guru dan orang tua menjawab bahwa " anak -anak sangat sengan dengan kegiatan di PAUD karena guru memvariasikan kegiatan bermain. Selain bermain dengan media big book, anakanak juga bermain balok, bermain olah 
Yaswinda, Yulsyofriend, Yaslina, Elida

ANALISIS PROGRAM PELATIHAN KADER PAUD TERINTEGRASI KELURAHAN ULAK KARANG SELATAN KOTA PADANG

Early Childhood: Jurnal Pendidikan. Vol. 3 No. 2., November 2019

raga dan senam di halaman PAUD. Selain itu anak-anak juga dilajarkan doa dan lagu-lagu anak-anak. Anak-anak juga diajarkan budaya antri dan berkata sopan. Orang tua juga sangat merasakanmanfaat dari PAUD yang gratis serta diberikan makanan sehat setiap masuk.

3). Apa kesulitan yang dihadapi ? Pada Guru menjawab "Salah satu kesulitan yang dihadapi, beradaptasi dengan anak".

\section{Pembahasan}

Langkah pertama sebelum pelatihan, perlu dilakukan analisis kebutuhan latihan secara cermat, karena pelatihan akan lebih efisien dan efektif, apabila peserta mendapatkan materi pelatihan yang sesuai dengan kebutuhannya. Ini perlu mendapat perhatian besar, karena latar belakang dan jenjang pendidikan peserta diklat cukup heterogen, dari indikasi ini sebenarnya kebutuhan materi pelatihan juga berbeda untuk setiap individu. Dalam kegiatan pelatihan, yang diutamakan adalah kegiatan berlatihnya bukan kegiatan melatih, artinya kegiatan/aktivitas peserta lebih diutamakan dan diperbanyak dari pada kegiatan/ aktivitas para pelatih atau fasilitatornya. Implikasi dari konsep ini cukup luas dalam perencanaan suatu pelatihan, karena yang menjadi pusat perhatian adalah kompetensi yang akan dicapai

Berdasarkan jawaban responden tentang waktu pelatihan pengetahuan sudah cukup, nmaun pelatihan praktik yang kurang. Hal ini menujukkan waktu pelatiahan dapat diterapkan kepada peserta pelatihan masih belum baik atau masih keteria cukup. Untuk itu perlu penambahan waktu untuk melaksanakan praktek pembuatan media dan praktek mengajarkan media kepada anak. Hal ini sesuai dengan teori bahwa Kemampuan belajar atau berlatih seseorang sangat dipengaruhi oleh: umur peserta, kapasitas untuk belajar, pemahaman yang dipelajari, tingkat aspirasi dan tujuan belajar (Padmowihardjo S. 1994: 40). Kemampuan belajar seseorang akan bertambah dengan cepat mulai lahir sampai mencapai puncaknya pada usia 25 tahun, kemudian akan menurun dengan kecepatan bertambah seiring bertambahnya umur. Hal ini disebabkan fungsi kerja otot semakin menurun, bukan karena kecerdasannya yang menurun, turunnya fungsi kerja otot dapat dilihat dari menurunnya. Jadi dengan bertambah usia, waktu pelatihan dapat ditambah.

Materi pelatihan secara umum dinilai peserta relevan dengan kebutuhan. Dari hasil diatas menuujukkan pemilhan tempat pelatihan sudah sesuai dengan kebutuhan peserta sehingga peserta pelatihan merasa nyaman dan dapat mengikuti pelatihan dengan baik. Pengelolaan program pelatihan lebih ditingkatkan lagi pelayanannya kepada peserta, agar pencapaian tujuan pelatihan lebih efisien dan efektif, peserta merasa puas (customer satisfaction) dengan layanan yang diberikan oleh penyelenggara 
Yaswinda, Yulsyofriend, Yaslina, Elida

\section{ANALISIS PROGRAM PELATIHAN KADER PAUD TERINTEGRASI KELURAHAN ULAK KARANG SELATAN KOTA PADANG \\ Early Childhood: Jurnal Pendidikan. Vol. 3 No. 2., November 2019}

pelatihan, dan kualitas penyelenggaraan program pelatihan dalam aspek-aspek yang bersifat teknis maupun substantif . salah satu pelayanan yang diberikan adalah penyediaan tempat penyelengaraan pelatihan.

Peserta pelatihan, menyatakan pelatihan ini bermanfaat, hal ini berarti pelatihan ini telah berhasil memberikan bekal kemampuan/ kompetensi dasar bagi peserta yang bermanfaat. Fasilitator melakukan pengamatan mendalam kepada 3 orang peserta pelatihan dan 7 orang tua siswa dengan mengajukan wawancara dengan hasil wawancara sebagai berikut.

Bagaimana kegiatan permaianan di PAUD berlangsung ? pada umumnya guru dan orang tua menjawab bahwa “ anak-anak sangat sengan dengan kegiatan di PAUD karena guru memvariasikan kegiatan bermain. Selain bermain dengan media big book, anakanak juga bermain balok, bermain olah raga dan senam di halaman PAUD. Selain itu anak-anak juga dilajarkan doa dan lagu-lagu anak-anak. Anak-anak juga diajarkan budaya antri dan berkata sopan. Hal ini sejalan dengan paradigma integrasi interkoneksi, serta implementasinya dalam pendidikan anak usia dini, mengingat pendidikan anak usia dini sangat penting dalam meletakkan keilmuan, moraltas serta spiritulitas anak. Hasil dari penelitian ini mengurangi ketegangan antara ilmu agama dan ilmu sosial lainnya. Paradigma ini menegaskan bahwa bangunan keilmuan apapuan, baik keilmuan agama, tidak dapat berdiri sendiri, akan tetapi membutuhkan kerja sama, saling tegur, saling koreksi dan saling keterhubungan, akan membantu manusia dalam menghadapi kompleksitas kehidupan manus (Najamuddin, Muhammad : 2016).

Orang tua juga sangat merasakan manfaat dari PAUD yang gratis serta diberikan makanan sehat setiap masuk. Pelayanan posyandu RW 01 di Ulak karang Selatan yang sebagai unit kesehatan berbasis masyarakat yang ada selama ini masih berfokus pada pelayanan penimbangan berat badan, pemberian vitamin A dan pemberian imunisasi serta belum mengintegrasikan dengan PAUD. Dengan memadukan program PAUD dan posyandu melalui Optimalisasi pelayanan PAUD terintergrasi yang bertujuan agar setiap balita mendapatkan pelayanan secara menyeluruh sesuai kebutuhan. Hasil dari kegiatan pengabdian ini berupa terjalinnya kerjasama antar kader melalui pelayanan integrasi, peningkatan pengetahuan kader tentang pertumbuhan dan perkembangan balita, sejalan dengan kegiatan implementasi Optimalisasi PAUD holistik di Desa Lemah mulya. Potensi tokoh masyarakat, kader dan warga masyarakat menjadi peluang terlaksananya. (Apriningrum, Nelly : 2018)

Bagaimana minat anak dengan PAUD? Pada umumnya mereka menjawab bahwa minat anak sangat tinggi. Ini ditandai dengan biasaya anak 
Yaswinda, Yulsyofriend, Yaslina, Elida

ANALISIS PROGRAM PELATIHAN KADER PAUD TERINTEGRASI KELURAHAN ULAK KARANG SELATAN KOTA PADANG

Early Childhood: Jurnal Pendidikan. Vol. 3 No. 2., November 2019

tidak mau bangun pagi, namun karena mereka sekarang masuk PAUD, pagipagi mereka sudah bangun dan minta mandi serta diantar ke PAUD. Dari hasil diatas terlihat kegiatan pelatihan ini bermanfaat dan dirasakan juga oleh siswa yang menjadi outcome perserta. Hasil ini sejalan dengan Komponen keluaran yaitu capaian kelompok anak yang terlibat cukup tinggi. Sebenarnya ada banyak anak yang mendaftar, sekitar 25 anak, namun usia masih 2 tahun sehingga belum diterima. Hasil ini tidak sejalan dengan Santi dkk, (2019), rendahnya pengetahuan kader BKB dan keluarga balita terhadap program BKB holisitik terintegrasi dengan Posyandu dan PAUD di Kota Sawahlunto. Berdasarkan analisis di atas, program pelatihan kader posyandu balita telah berlangsung dnegan baik Karena adanya keterlibatan semua pihak dalam mewujudkan berdirinya PAUD terintegrasi di wilayah pesisir Ulak Karang Selatan. Hal ini sejalan Rajab (2018) dengan Pembangunan pendidikan di desa pesisir dengan Kegiatan pemberdayaan dilakukan dengan melibatkan semua pihak, baik pemerintah, masyarakat, dan perguruan tinggi sebagai perwujudan pelaksanaan kegiatan pengabdian terhadap masyarakat

\section{SIMPULAN}

Pelatihan untuk kader PAUD yang terintegrasi dengan posyandu Balita dengan nama PAUD Pasia Mutiara telah berjalan dengan baik. Para kader dapat melakukan inovasi dalam pengembangan POS PAUD integrasi ini. Layanan termasuk penyebaran pengetahuan makanan yang sehat untuk balita. Berdasarkan analisis CIPP, maka program telah berjalan dengan baik, sesuai rencana dengan melibatkan banyak pihak dan memberikan dampak manfaat bagi anak usia dini dan orang tua serta kader posyandu balita. Kegiatan lanjutan adalah pemantapan kegiatan integrasi dengan pendampingan oleh tim pengabdi.

\section{DAFTAR PUSTAKA}

Manat, Rahim, dkk. 2014. model pemerdayaan masyarakat di wilayah pesiisr dalam menanggulangi kemiskinan di kabupaten buton, sulawesi tenggara. Jurnal The Winners, vol 15 No 1:23-33

Rajab, Arha Muhammad. dkk. 2018. Pemberdayaan Masyarakat Desa Pesisir Dalam Pengembangan Pendidikan Dan Teknologi Informasi Di Kabupaten Pinrang Provinsi Sulawesi Selatan. Prosiding Seminar Hasil Pengabdian(SNP2M) (pp461466). 978-602-60766-5-6.

Sujiono, Yuliani Nuraini.2012.Konsep Dasar Pendidikan Anak Usia Dini.Jakarta:Indeks 
Yaswinda, Yulsyofriend, Yaslina, Elida

ANALISIS PROGRAM PELATIHAN KADER PAUD TERINTEGRASI KELURAHAN ULAK KARANG SELATAN KOTA PADANG

Early Childhood: Jurnal Pendidikan. Vol. 3 No. 2., November 2019

Trianto.2011.Desain Pengembangan

Models \& Application. San

Pembelajaran Tematik. Jakarta :

Frabcisco: Jossey-Bass Inc.

Kencana Prenada Media Group

Hariani, Santi dkk. Analisis Kebijakan

Program Bina Keluarga Balita

(BKB) Holistik Terintegrasi

Dengan Posyandu dan PAUD di

Kota Sawahlunto Tahun 2016.

Jurnal Kesehatan Andalas. 2019:8(1).

Najamuddin Muhammad. 2016. Pendekatan integrasi-interkoneksi dalam pendidikan PAUD. Jurnal ilmiah tumbuah kembang anak usia dini, vol.1 no. 1. EISSN:2502-3519

Apriningrum, Nelly. 2018. Optimalisasi Pelayanan Paud Holistik Melalui Pelatihan Kader Di Desa Lemah Mulya Kecamatan Majalaya Kabupaten Karawang. Jurnal Cemerlang Pengabdian pada Masyarakat. Vol. 1. No. 1, 3757. ISSN 2654-4741. DOI: https://doi.org/10.31540/jpm.v1i1 .140

Suharsimi Arikunto \& Abdul Jabar (2009). Evaluasi Program Pendidikan: Pedoman Teoretis Praktis bagi Mahasiswa dan Praktisi Pendidikan. Edisi Kedua. Jakarta: PT. Bumi Aksara

Stufflebeam, D.L. (2003). Evaluation as enlightment for decisión making. Columbus, Ohio: Ohio State University.

Stufflebeam, DL \& Shinkfield, AJ (2007). Evaluation, Theory, 